\title{
Kajian Simulasi Mikromagnetik: Ketergantungan Medan Koersif dengan Besaran Intrinsik Nano-Dot Magnetik dengan Anisotropi Tegak Lurus
}

\author{
Budi Purnama,* Ismail, dan Suharyana \\ Jurusan Fisika-FMIPA, Universitas Sebelas Maret (UNS) \\ Jl. Ir. Sutami 36A Kentingan 36A, Surakarta 57126
}

\begin{abstract}
Intisari
Kajian simulasi mikromagnetik magnetisasi reversal pada nano-dot magnetik dengan anisotropi tegak lurus telah dilakukan dengan menyelesaikan persamaan Landau-Lifshitz-Gilbert. Model yang disimulasikan nano-dot bahan magnetik pada unit sel Heat Assisted Magnetic Recording (HAMR) dengan dimensi $50 \mathrm{~nm} \times$ $50 \mathrm{~nm} \times 20 \mathrm{~nm}, 4 \pi \mathrm{M}_{S}=2500$ gauss, $\mathrm{T}_{C}=373 \mathrm{~K}$ dan konstanta anisotropi $\mathrm{K}_{\perp}=5.10^{5} \mathrm{erg} / \mathrm{cm}^{3}$. Simulasi ini dilakukan untuk mengetahui faktor-faktor fisis yang berpengaruh pada koersifitas dari pengamatan proses magnetisasi reversal. Hasil simulasi menunjukkan medan koersif meningkat sebesar $18 \%$ dengan penurunan redaman Gilbert dari $\alpha=1$ hingga $\alpha=0,3$. Akhirnya, peningkatan medan koesif juga teramati sebesar $32,7 \%$ dengan penurunan konstanta exchange stiffness dari $\mathrm{A}=1.10^{-6} \mathrm{erg} / \mathrm{cm}$ hingga $\mathrm{A}=1.10^{-7} \mathrm{erg} / \mathrm{cm}$.
\end{abstract}

\begin{abstract}
Micromagnetic magnetization reversal simulation study of magnetic nano-dot with perpendicular anisotropy has been performed by solving the Landau- Lifshiz-Gilbert equation. A model simulated is magnetic nano-dot materials as considering Heat Assisted Magnetic Recording (HAMR) cell units with dimensions of $50 \mathrm{~nm} \times 50$ $\mathrm{nm} \times 20 \mathrm{~nm}, 4 \pi \mathrm{M}_{S}=2500$ gauss, $\mathrm{T}_{C}=373 \mathrm{~K}$ and anisotropy constant $\mathrm{K}_{\perp}=5.10^{5} \mathrm{erg} / \mathrm{cm}^{3}$. The simulation was conducted to determine physical factors that affect to coercive field. Simulation results show the coercive field increased by $18 \%$ with decreased Gilbert damping constant from $\alpha=1$ to $\alpha=0.3$. Finally, the increased of coercive field also observed by $32.7 \%$ with decreased exchange stiffness constant from $\mathrm{A}=1.10^{-6} \mathrm{erg} / \mathrm{cm}$ to $\mathrm{A}=1.10^{-7} \mathrm{erg} / \mathrm{cm}$.
\end{abstract}

KATA KUNCI: micromagnetic simulation, hysteresis curve, coercive field, HAMR

\section{PENDAHULUAN}

Ketersediaan bahan magnet dengan anisotropi magnetik tinggi, telah membuka peluang pemanfaatan yang semakin luas di industri teknologi informasi. Tidak hanya sebagai bahan dasar magnet permanen saja, karakteristik bahan yang stabil dengan panas telah membuka peluang pemanfaatan secara luas sebagai unit storage sel memori pada teknologi perekaman, yakni bahan magnet ini dapat diaplikasikan sebagai media perekaman. Artinya, bahan magnet dengan anisotropi tinggi ini tidak akan kehilangan karakter magnet ketika dipattern hingga orde nm akibat efek panas. Terlebih penemuan bahan magnet dengan anisotropi tegak lurus yang secara teori tidak ada pembatasan rasio dimensi sel dalam mem-pattern. Sedangkan teknologi HAMR diyakini sebagai salah satu metode read-write masa depan yang menggantikan teknologi media perekaman saat ini guna menghadirkan kera-

\footnotetext{
*E-MAIL: bpurnama@gmail.com
}

patan penyimpanan data hingga mencapai 10 Tbit/inch $^{2}[1,2]$.

Secara eksperimen, telah banyak dilaporkan berbagai metode untuk meningkatkan anisotropi yang terungkap dari besarnya nilai medan koersif ketika proses magnetisasi reversal. Namun demikian, peningkatan medan koersif belum diketahui secara pasti mekanisme. Secara umum, dua parameter fisika yang dianggap sebagai penyebab peningkatan nilai medan koersif domain wall pinning akibat ketidaksempurnaan struktur kristal penyusun lapisan tipis dan exchange stiffness.

Pada penelitian ini, medan koersif akan dikaji ketergantungannya dengan parameter intrinsik bahan magnetik yaitu konstanta redaman Gilbert dan exchange stiffness. Redaman Gilbert $(\alpha)$ dipahami sebagai fenomena relaksasi spin dan mengontrol kecepatan magnetisasi spin mencapai kesetimbangan [3, 4]. Sedangkan exchange stiffness adalah besaran yang mengatur derajat koheren magnetisasi reversal. Mikromagnetik simulasi yang dilakukan ini akan mengevaluasi ketergantungan medan koersif karena dua parameter intrinsik tersebut. Selain itu, perubahan mode magnetisasi juga menjadi bagian tidak terpisahkan dari kajian ini. 


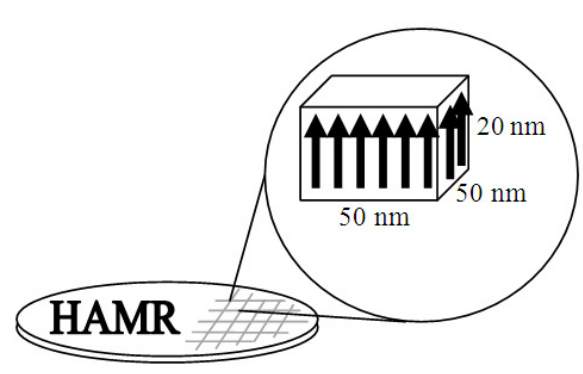

Gambar 1: Diagram skematik model simulasi

\section{METODOLOGI}

Dalam simulasi mikromagnetik ini, nano dot magnetik dengan anisotropi tegak lurus dibagi-bagi menjadi array dua dimensi pada grid numerik. Ukuran grid ditetapkan lebih kecil dari lebar domain wall. Medan demagnetisasi dihitung dengan meng-integral-kan dari permukaan bahan magnetik pada tiap elemen grid. Pendekatan untuk efek fluktuasi suhu yang muncul selama magnetisasi dihitung dengan menganggap resultan medan efektif yang disumbang orientasi acak magnetisasi bernilai nol $\left(\mathrm{H}_{f}(\mathrm{t})=0\right)$. Medan yang digunakan untuk satu proses magnetisasi dihitung dengan menyelesaikan persamaan Landau-Lifshitz-Gilbert (LLG) [1],

$$
\begin{aligned}
\frac{d \mathbf{M}^{i}}{d t} & =-|\gamma| \mathbf{M}^{i} \times \mathbf{H}_{e f f}^{i}+\frac{\alpha}{M_{S}} \times \frac{d \mathbf{M}^{i}}{d t} \\
\mathbf{H}_{e f f} & =\mathbf{H}_{e x}+\mathbf{H}_{k}+\mathbf{H}_{d}+\mathbf{H}_{f}
\end{aligned}
$$

dengan $\mathbf{M}$ adalah magnetisasi, $\gamma$ adalah rasio gyromagnetik, $\alpha$ adalah konstanta redaman Gilbert, $\mathbf{H}_{e f f}$ adalah medan efektif, dan $\mathbf{M}_{s}$ adalah magnetisasi saturasi. $\mathbf{H}_{e x}, \mathbf{H}_{k}$, dan $\mathbf{H}_{d}$ adalah medan exchange, medan anisotropi, dan medan demagnetisasi. $\mathbf{H}_{f}$ adalah medan karena fluktuasi suhu.

Dalam simulasi ini nano dot magnetik berdimensi $\mathrm{p} \times \ell \times$ $\mathrm{t}=50 \mathrm{~nm} \times 50 \mathrm{~nm} \times 20 \mathrm{~nm}$ ditinjau sebagai unit sel pada HAMR. Bahan magnetik ini memiliki anisotropi tegak lurus dengan parameter fisis sebagai berikut, rasio gyromagnetik $\gamma$ $=1,76.10^{7} /$ Oe.s, $\mathrm{K}_{\perp}=5.10^{5} \mathrm{erg} / \mathrm{cm}^{3}, 4 \pi \mathrm{M}_{S}=2500$ gauss, $\mathrm{T}_{c}=373 \mathrm{~K}$ serta step intergrasi 0,12 ps. Secara skematik ditunjukkan pada Gambar 1.

Ketergantungan suhu dengan penurunan magnetisasi secara termal diasumsikan untuk konstanta exchange stiffness (A), dan anisotropi tegak lurus $\left(\mathrm{K}_{\perp}\right)$, dituliskan sebagai [5]

$$
\begin{aligned}
A(T) & =A^{\circ}\left(\frac{M_{S}(T)}{M_{\circ}(T)}\right)^{2} \\
K_{\perp}(T) & =K_{\perp}^{\circ}\left(\frac{M(T)}{M(T)}\right)^{2}
\end{aligned}
$$

Sedangkan ketergantungan mangetisasi terhadap suhu secara sederhana dengan dinyatakan rumus

$$
M(T)=M(0)\left(1-\frac{T}{T_{C}}\right)^{0,5}
$$

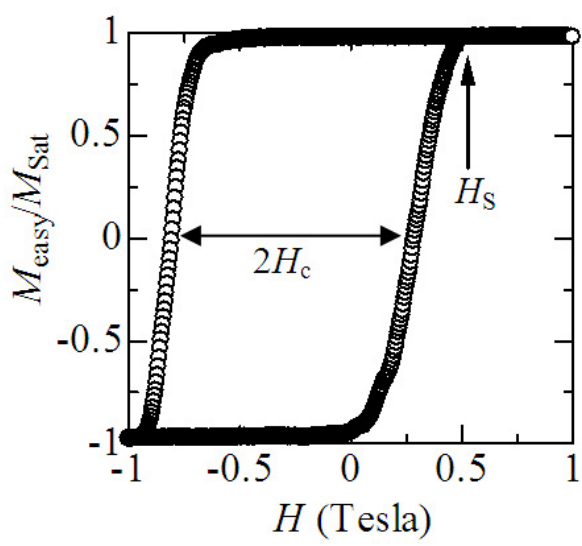

Gambar 2: Profil kurva histeresis hasil simulasi

\section{HASIL DAN DIKUSI}

Profil kurva histeresis hasil simulasi mikromagnetik ditunjukkan pada Gambar 2. Kurva tersebut diperoleh dari simulasi mikromagneitik dengan parameter redaman Gilbert $\alpha=$ 0,3 dan konstanta exchange stiffness $\mathrm{A}=1 \cdot 10^{-7} \mathrm{erg} / \mathrm{cm}$ yang dilakukan pada suhu ruang $298 \mathrm{~K}$.

Teramati dengan jelas bahwa karakter kurva yang kotak terbentuk. Hal ini menunjukkan ferromagnetisme yang sangat kuat. Namun demikian, sejak awal pembentukan dinding domain hingga sempurna reversal memerlukan medan jenuh, $\mathrm{H}_{S}=4500$ Oe. Hal ini menunjukkan bahwa proses magnetisasi melalui domain wall nukleasi diikuti perambatan dinding wall, hanya merupakan salah satu faktor. Faktor lainnya yang menentukan mode magnetisasi reversal adalah medan anisotropi, $\mathrm{H}_{k}=2 \mathrm{~K}_{\perp} / \mathrm{M}_{S}$. Perhitungan nilai $\mathrm{H}_{k}$ untuk besaran fisis yang terungkap pada kurva hysteresis Gambar 1 adalah 10.000 Oe. Sedangkan nilai medan koersif $\left(\mathrm{H}_{c}\right)$ dari perhitungan ini sebesar 5,4 kOe.

Salah satu besaran intrinsik bahan magnetik adalah konstanta redaman Gilbert. Besaran ini menentukan laju relaksasi sesaat setelah medan luar penginduksi dihilangkan. Secara teoritis, besaran ini menarik untuk dikaji. Untuk itu pada simulasi ini dilakukan variasi nilai redaman Gilbert sebesar $\alpha$ $=0,3, \alpha=0,4, \alpha=0,5, \alpha=0,6$ dan $\alpha=1$.

Hasil variasi ini menunjukkan semakin besar nilai redaman Gilbert akan menyebabkan koersifitas semakin kecil. Namun demikian beda antara medan nukleasi $\mathrm{H}_{n}$ dan medan saturatsi $\mathrm{H}_{s}$ semakin kecil, yang mengindikasikan mode magnetisasi spontan. Hubungan mode magnetisasi dengan redaman Gilbert dapat dinyatakan dengan kurva slope kurva histeresis sebagai fungsi redaman Gilbert. Teramati dengan jelas bahwa $\mathrm{H}_{c}$ meningkat secara drastis dengan penurunan nilai $\alpha$.

Untuk $\alpha=1$ nilai $\mathrm{H}_{c}=4,5 \mathrm{kOe}$, sedangkan pada $\alpha=0,3$, $\mathrm{H}_{c}$ meningkat menjadi 5,4 kOe. Perubahan redaman sebesar $0,7(=1-0,3)$ menyebabkan peningkatan koersifitas sebesar $18 \%$.

Aspek lain yang perlu dikonfirmasi terhadap mode magnetisasi reversal adalah efek perubahan konstanta exchange stiffness (A). Gambar 5(a) memperlihatkan perubahan kurva 


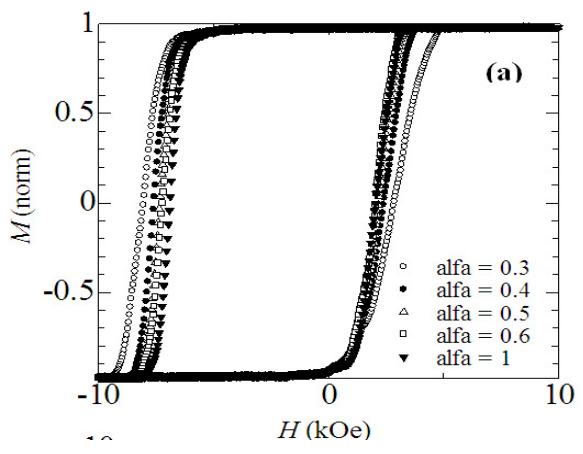

(a)

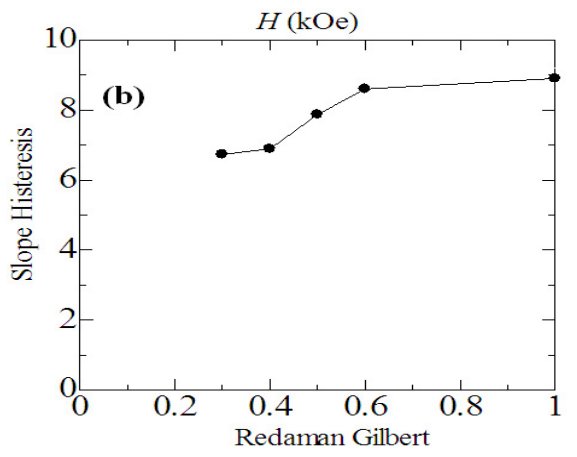

(b)

Gambar 3: Tipikal perubahan kurva histeresis karena pengaruh redaman Gilbert

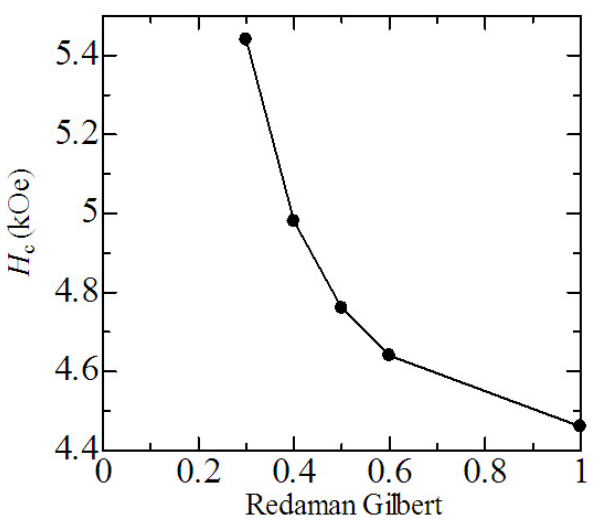

Gambar 4: PKetergantungan Hc sebagai fungsi redaman Gilbert

histeresis dengan variasi exchange stiffness (A) yaitu $1.10^{-7}$ $\mathrm{erg} / \mathrm{cm}, 5.10^{-7} \mathrm{erg} / \mathrm{cm}, 1.10^{-6} \mathrm{erg} / \mathrm{cm}$. Teramati jelas pada kurva untuk nilai $\mathrm{A}=1.10^{-7} \mathrm{erg} / \mathrm{cm}$, beda nilai medan nukleasi $\mathbf{H}_{n}$ dan medan saturasi $\mathbf{H}_{s}$ pada kurva histeresis berbeda secara signifikan. Hal ini mengindikasikan mode magnetisasi reversal berlangsung melalui domain wall nukleasi dilanjutkan domain wall propagasi. Hal sebaliknya, saat $\mathrm{A}=$ $1.10^{-6} \mathrm{erg} / \mathrm{cm}$, kurva histeresis terbentuk lebih sempit dengan beda $\mathbf{H}_{n}$ dan $\mathbf{H}_{s}$ kecil. Hal ini menunjukkan magnetisasi reversal terjadi secara spontan. Perbedaan mode magnetisasi ini yang disinyalir sebagai penyebab perubahan nilai medan koersive yang teramati.

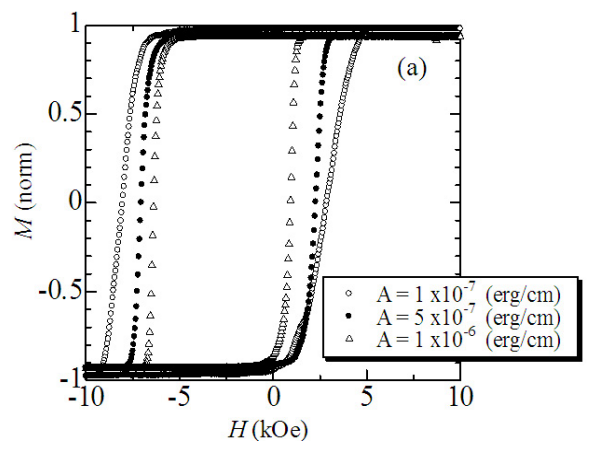

(a)

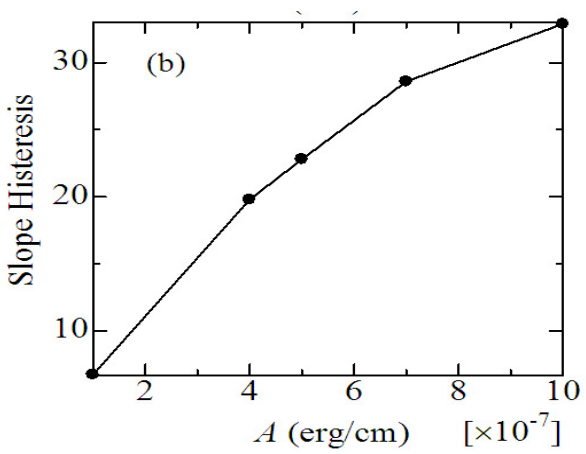

(b)

Gambar 5: Ketergantungan Hc sebagai fungsi redaman Gilbert

Perubahan mode magnetisasi reversal akibat perubahan exchange stiffness, juga bisa disajikan kurva slope histeresis sebagai fungsi exchange stiffness A yang ditunjukkan pada Gambar 5 (b). Perubahan signifikan mode magnetisasi reversal ini dapat dijelaskan sebagai berikut. Nilai exchange stiffness yang semakin besar menunjukkan interaksi antar momen magnetik atom yang semakin kuat. Dalam hal ini masingmasing momen magnetik atom mempengaruhi momen magnetik atom lain untuk memiliki arah magnetisasi seragam dengan dirinya. Sehingga ketika bahan yang memiliki exchange stiffness lebih besar diinduksi oleh medan luar maka momen magnetik akan merespon secara koheren, dengan hasil koersifitas lebih kecil. Dengan kalimat lain diperlukan medan koersif kecil untuk menghilangkan magnetisasi sisa pada bahan yang memiliki interaksi antar atom kuat.

Berdasarkan bentuk kurva histeresis hasil simulasi di atas, dapat diplot $\mathbf{H}_{c}$ vs exchange stiffness A yang ditunjukkan Gambar 6. Secara umum, $\mathbf{H}_{c}$ menurun secara eksponensial dengan kenaikan exchange stiffness A. Saat $\mathrm{A}=1.10^{-7}$ $\mathrm{erg} / \mathrm{cm}$ magnetisasi reversal yang terungkap dari kurva histeresis merealisasi nilai medan koersif 5,4 kOe, sebaliknya secara kontras ketika nilai $\mathrm{A}=1.10^{-6} \mathrm{erg} / \mathrm{cm}$ nilai $\mathbf{H}_{c}=$ 3,7 kOe. Kenyataan ini memperlihatkan bahwa dengan penurunan nilai exchange stiffness sepuluh kali menyebabkan kenaikan $\mathbf{H}_{c}$ hingga $32,7 \%$.

Pengaruh variasi exchange stiffness terhadap bentuk kurva histeresis dan slope histeresis seperti yang ditunjukkan seperti hasil di atas menunjukkan tipikal yang sama dengan hasil eksperimental penelitian yang dilaporkan sebelumnya $[6,7]$. 


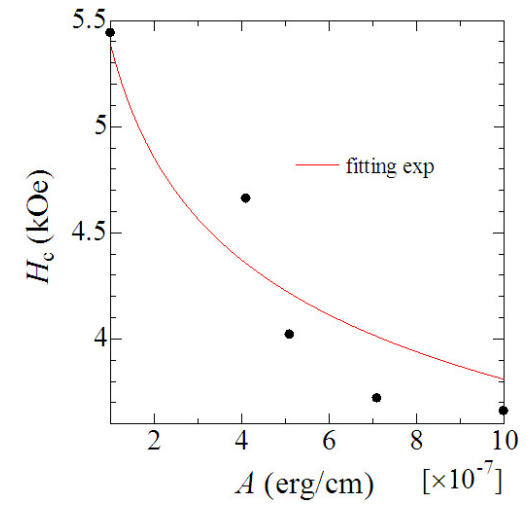

Gambar 6: Grafik hubungan $\mathrm{H}_{c}$ dengan exchange stiffness A

\section{SIMPULAN}

Kajian simulasi mikromagnetik magnetisasi reversal pada nano-dot magnetik dengan anisotropi tegak lurus telah dilakukan dengan menyelesaikan persamaan Landau-LifshitzGilbert. Simulasi ini dilakukan untuk mengetahui faktorfaktor fisis yang berpengaruh pada koersifitas dari pengamatan proses magnetisasi reversal. Hasil simulasi menunjukkan medan koersif meningkat sebesar $18 \%$ dengan penurunan redaman Gilbert dari $\alpha=1$ hingga $\alpha=0,3$. Akhirnya, peningkatan medan koesif juga terjadi karena penurunan konstanta exchange stiffness dari $\mathrm{A}=1.10^{-6} \mathrm{erg} / \mathrm{cm}$ hingga $\mathrm{A}=$ $1.10^{-7} \mathrm{erg} / \mathrm{cm}$ yaitu sebesar $32,7 \%$.
[1] K. Shiiki, and H. Motojima, Journal of Physics, Conference Series, 200 (2010).

[2] T. Schrefl, et all., Applied Computing Conference, Istanbul, Turkey (2008).

[3] M.C. Hickey, and J.S Moodera, Physical Review Letters 102, 137601 (2009).

[4] T. Schrefl, et all., Micromagnetic Simulation of Dynamics and Thermal Effect (Handbook of Advanced Magnetic Materials Vol.
1, 2006 Hal. 128).

[5] M. Mansuripur and G.A.N Connel, J. Appl. Phys 55, 3049 (1984).

[6] E. Miyashita, et all., IEEE Trans. on Magn., 38 No 5(2002).

[7] H.J. Richter, The Physics of Perpendicular Recording(Seagate Technologi, Fremont, 2006). 